\title{
Patia of Eastern India. Vestiges of a reverse clinker tradition
}

Patia of Eastern India. Vestiges of a Reverse Clinker Tradition

Patia de la India del este. Vestigios de una tradición del tingladillo invertido

\section{Swarup Bhattacharya and Lotika Varadarajan}

\section{(2) OpenEdition}

\section{Journals}

Electronic version

URL: https://journals.openedition.org/tc/304

DOI: $10.4000 /$ tc. 304

ISSN: 1952-420X

\section{Publisher}

Éditions de l'EHESS

\section{Printed version}

Date of publication: 1 January 2001

Number of pages: 417-444

ISSN: 0248-6016

\section{Electronic reference}

Swarup Bhattacharya and Lotika Varadarajan, "Patia of Eastern India. Vestiges of a reverse clinker tradition", Techniques \& Culture [Online], 35-36 | 2001, Online since 10 September 2012, connection on 29 September 2022. URL: http://journals.openedition.org/tc/304 ; DOI: https://doi.org/10.4000/tc.304

This text was automatically generated on 29 September 2022.

All rights reserved 


\section{Patia of Eastern India. Vestiges of a reverse clinker tradition}

Patia of Eastern India. Vestiges of a Reverse Clinker Tradition

Patia de la India del este. Vestigios de una tradición del tingladillo invertido

\section{Swarup Bhattacharya and Lotika Varadarajan}

1 The patia is a boat in which three methods of horizontal plank joinery may be found. These comprise reverse clinker, carvel and clinker. In modern times the patia is found exclusively in the Digha area adjoining the Subarnarekha river in West Bengal and in the contiguous coastal territory of Orissa (fig. 1). Neither the boat builders nor those who ply it demonstrate any significant markers of « modernity » insofar as systems of carpentry assemblage are concerned. 


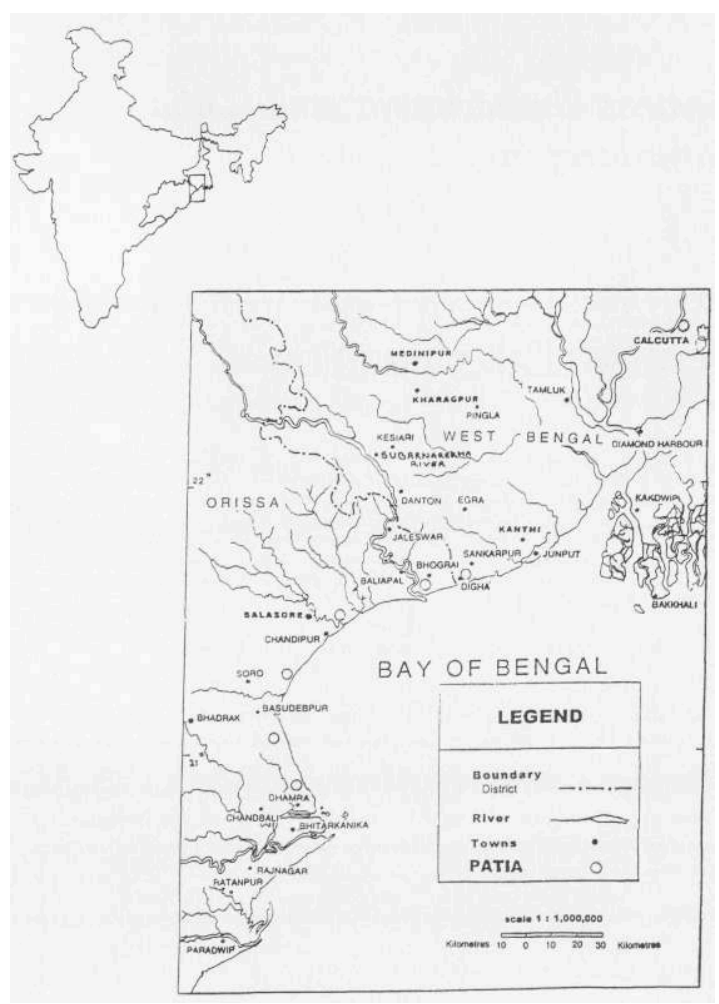

Figure 1. Distribution of patia in West Bengal and Orissa

However, there has been considerable innovation in the area of carpentry tools. It is significant that the absence of commercialisation in boat building is paralleled by the high degree of symbolism inherent to this boat.

The maximum length of this boat in which the reverse clinker section plays a crucial role, is 30 hat ( 1 hat is equal to $\left.1,5^{\prime}\right), 45^{\prime}$ and the minimum 10 hat, $15^{\prime}$. The degree of overlap in the reverse clinker segment differs according to specific positioning in the hull. The reverse clinker joinery is used in the water line section of the floor of the hull, extending upwards upto points of termination at both stem and stern end regions. Professor K.S. Behera, (Head, Department of History -retired-, Utkal University, Bhubaneshwar), has pointed out that both clinker and reverse clinker plank joinery are much in evidence in the Orissan boat building tradition. Because of the variations in clinker carpentry prevalent at Balasore, he feels this may have been the nuclear centre for this form in Orissa. The reverse clinker tradition is also to be found in the south Medinipur area of West Bengal. South Medinipur, in fact, enjoys an extensive common border with parts of north Orissa ${ }^{3}$. The presence of the reverse clinker tradition in this region, therefore, need elicit no surprise.

\section{Raw Materials}

4 The wood used in patia making include arjun (Terminalia arjuna), babla (Acasia arabica), sirish (Albizzia lebbek), and khirish (Samania saman). Sal, (Shorea robusta) is prized but is too expensive even though the life of a boat made of sal is much longer than that of arjun. Arjun is the most popular choice because it is lighter and has a greater affinity for salt water. It is cheap and is available locally. The aspect of weight is also an important consideration. The littoral of the Bay of Bengal is subject to cyclones. Fishermen, who 
fish at sea in patia, tend to shore their vessels when not in use. On occasion, safety from the vagaries of nature can be sought by dragging the boat inland over distances of as much as 100 metres. The main source of wood is that obtained from wood merchants and sawmills. The sawmills are located at Ramnagar and Kanthi at a distance of $7 \mathrm{~km}$ and $25 \mathrm{~km}$ respectively from Digha. Usually the owners buy wood of their choice from wood merchants and get these sawn into planks under the supervision of the head carpenter. The master carpenter prefers wood with the desired sap content. The wood is measured in cubic feet, called sefti locally. The volume of the wood is calculated on the basis of circumference of the log at the mid section multiplied by its length. The unit price ( 1 ' of circumference by $1 / 2^{\prime}$ in length) is ascribed on the basis of the quality of the wood. The concept of measurement in terms of cubic feet is quite alien to the indigenous tradition ${ }^{4}$. Seasoning is simple. During the period of the Northeast monsoon, logs are stored under cover for drying without exposure to the sun.

Unlike the West Bengal dingi, which is stapled, the Orissa patia is nailed. Nails, perek, usually of between $4 "$ to $6 "$ in length, are procured from local hardware shops.

\section{Organisation of Boat Building}

6 Patia building is not a commercial activity as is the case with dingi construction at Sripur-Balagarh, district Hugli, West Bengal. Boat builders generally hail from families traditionally engaged in this activity. As such the skill content is high and linkages between patron and boat builder transcend the purely utilitarian considerations which prevail in a market dominated economy. Symbolical and ritual considerations are integral to the ties binding the boat builder to his patron on the one hand, and to his creation, the patia, on the other.

7 In Digha, district Medinipur, West Bengal, Sudhir Jana, a patia builder, hails from a family that has practiced this occupation for six generations. Unlike Balagarh where the fixing of staples, jolui, and caulking, gaoni, are handled by specialised groups, the master builder of patia assumes total responsibility for all aspects of boat building. He chooses his team and is accepted as master on account of his knowledge, managerial ability, skill, and intelligence. This kind of work organization could be taken as a parameter for assessing whether or not a particular artisanal activity can be classified as hereditary. In the case of the relatively new hybrid tradition of manufacture of the trawler at Kakdwip, Sundarbans, South Twenty-Four Parganas, master carpenters can be young and be first generation boat builders as demonstrated in the case of Kala Chand Dhali aged about thirty-eight. In Orissa, patia builders live in different parts of Balasore district but they maintain regular contact with coastal fishermen as well as those living along the banks of the Subarnarekha River.

8 The order for building a boat is procured on a contract basis which is, however, not time bound. The boat building team lives in the house of the patron who provides full hospitality. The expenses of travel are also borne by the patron. Boat building activity is carried out in the open within the premises of the owner. Although the owner is knowledgeable about the exigencies of patia building and lends a willing hand when required, all carpentry decisions are taken by the master carpenter who has the final say. However, this activity is extremely dependent on close teamwork. Usually the chief carpenter employs two helpers paid on a contractual or daily wage basis (photo 1). 
Patias are always made to specific order. The owner defines the desired length. All other measurements are taken in proportion to this dimension.

For Patia Building, the wood selected is taken to the sawmill (if purchased from a stockist), or it is chosen at the sawmill itself. The master carpenter usually makes this choice. He brings a helper with him and has the wood is sawn according to his directions. A few extra planks are also included to cover possible wastage.

\section{Bending}

10 The first stage in the process is the bending of the planks as required. A trench is prepared, the length depending on the length of the planks which are to be bent. The fuel used comprises straw and scraps wood. The logs to be curved are covered on one side with a solution of fresh cowdung. One lump of dung is sufficient for a single plank. The dung is kept in a semi-solid state in a pot and is applied by a brush.

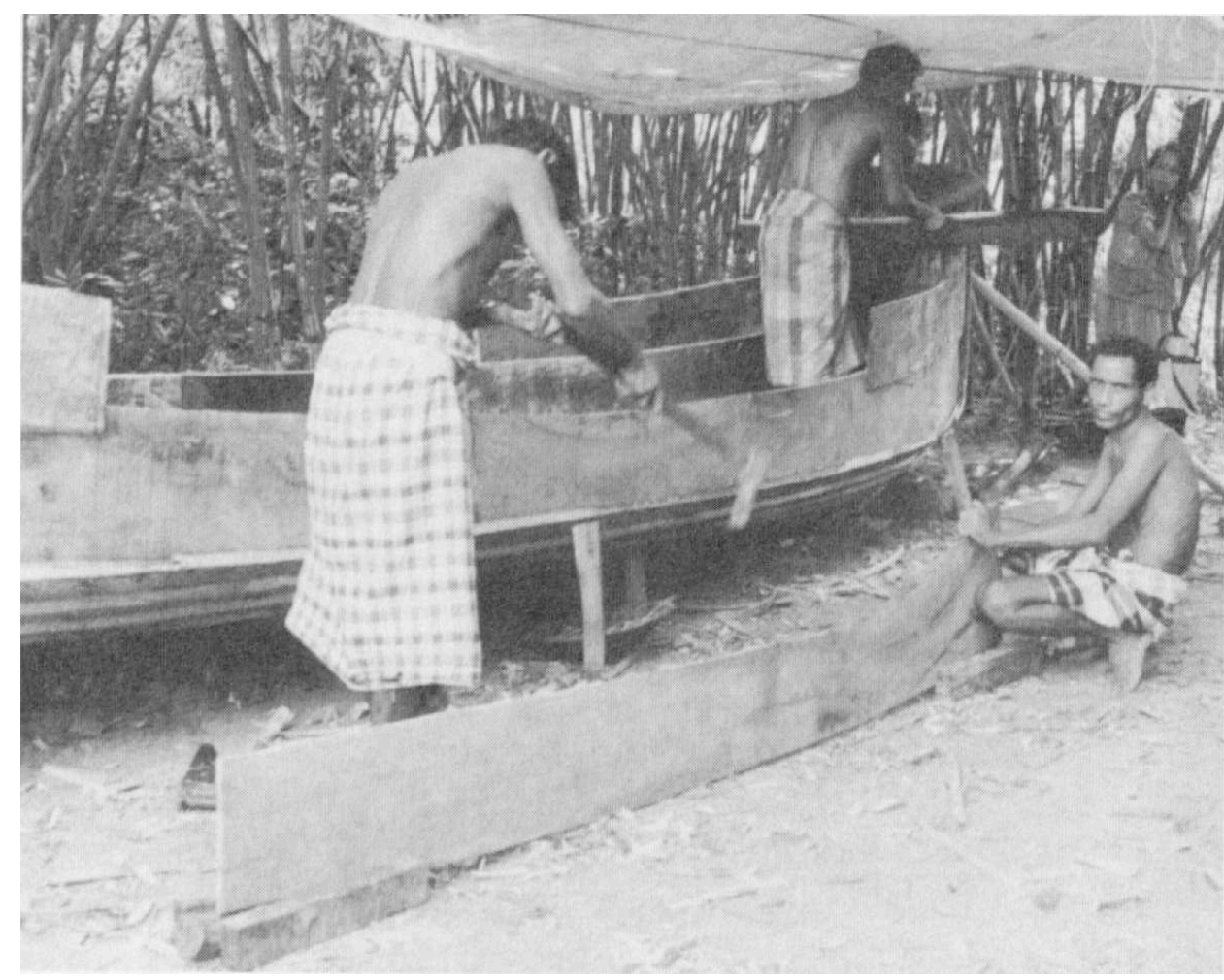

Photo 1. The master carpenter, Bangsidhar Gangahai, age 55 and his team at work. Bangsidhar Gangahai hails from the village of Rosolpur, Bhograi Police Station, district Balasore, Orissa. He is building a patia for Arjun Behra, village Paschim Godadharpur, Police Station Digha, District Medinipur. The owner's daughter has brought tea in a flask for the carpenters. Note the cloth awning above the boat

11 After heating, the planks are immediately taken to an adjacent place where bending is to be accomplished by means of an instrument called meri kat. At ground level the meri kat comprises a rounded log of wood, usually the trunk of palm or coconut. The ground is lightly dug out to accommodate the rounded shape. On the lower surface a section of wood is placed lengthwise supported by two blocks of wood. This acts as a kind of pivot ensuring that the rounded log will return to its central position each time the frame is turned and released. The plank to be bent is wedged beneath a frame. There is a gap of $4 "$ to 5 " between this frame and the surface of the log. One end of the plank is pushed 
up by the height of the base log as it is being eased through from the lower end. The two long poles set 2' apart in an upright position serve as handles, which roll the log from one periphery to the other (photo 2). The plank may be heated more than once to ensure correct curvature.

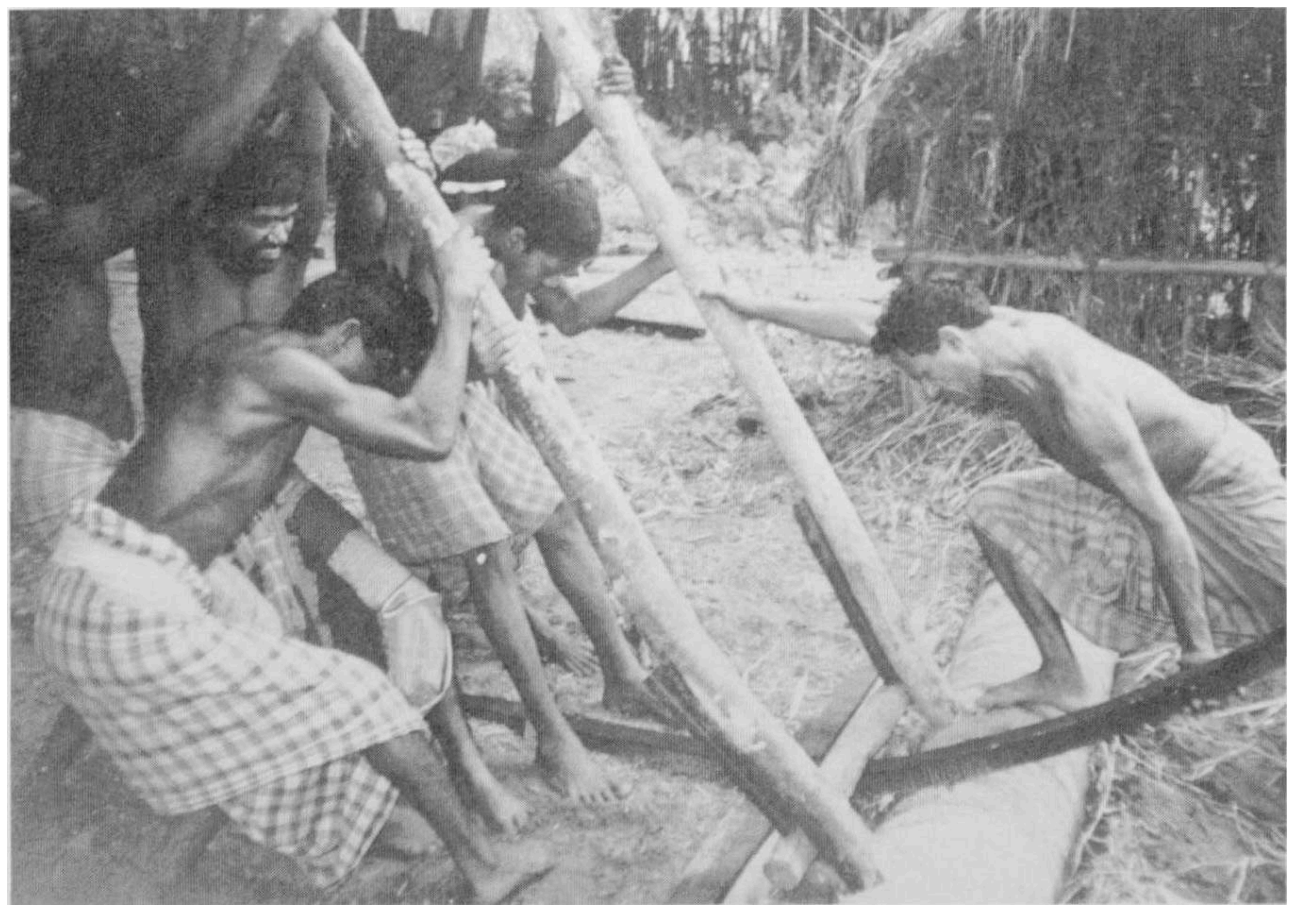

PHOTO 2. WHILE THE HeLPERS PULL THE hANDLES THE MASTER CARPENTER MANIPULATES THE PLANK AND guides THE PRESSURE POINTS ON THE PLANK

\section{Keel Laying}

12 As has been stated the patia, unlike the majority of the boats of West Bengal, has a keel called danda. This is made from a long hard piece of wood 3" square in cross section. The lower surface is $\mathrm{V}$ shaped to minimise friction with water. The joinery used for lengthening the danda is the dar sad (scarf joint) of Balagarh, referred to as khamci or jhinjhre khaj here (fig. 2). Sometimes this can be further strengthened by a key, khil. Although the basic bending of the keel has been already accomplished through the meri $k a t$, the final shaping is provided by elements in the support system of the danda.

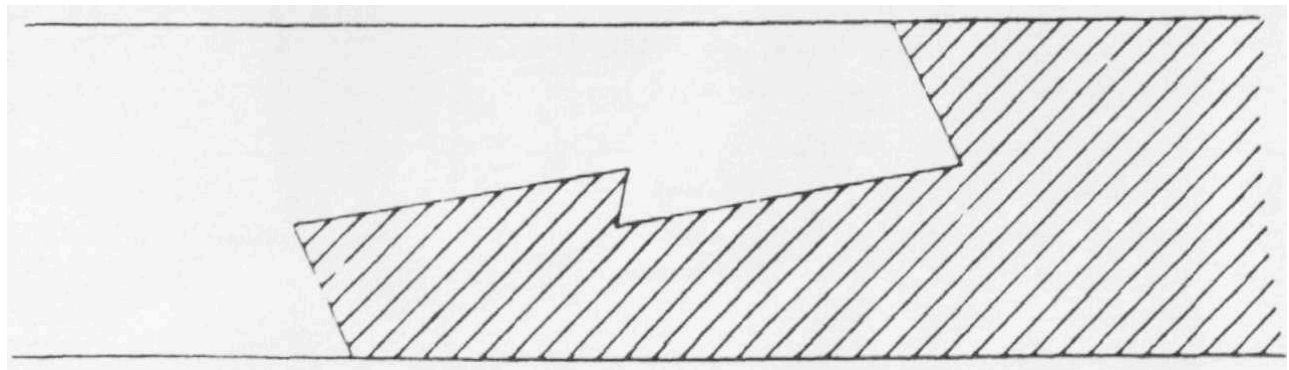

Figure 2. Scarf joint, khamci 


\section{The Support System}

Two wooden logs, gor, are placed on the ground just prior to the point where the upward curvature commences towards both the stem and stern ends. Bamboo poles provide support to the stem, ani, and stern, picha. The kilti device facilitates the upward curvature at the stem and stern ends. In this, a wedge is nailed onto the danda. The wedge is tied by a rope to a bamboo log driven transversally into the ground. This exercises an outward thrust to the danda at the desired point (fig. 3). The distance for the placement of kilti is measured from the terminal ends of the danda taken along its circumference. The positioning of the kilti is proportionate to the length of the danda as follows :

\begin{tabular}{|c|c|c|}
\hline Length of danda & \multicolumn{2}{|c|}{ Placement of kilti } \\
\hline & Stem & Stern \\
\hline 16 hat & 6 cankhor & 4 cankhor \\
\hline 17 hat & 7 cankhor & 4 cankhor \\
\hline 18 hat & 7.5 cankhor & 4.5 cankhor \\
\hline 19 hat & 8 cankhor & 4.5 cankhor \\
\hline 20 hat & 9 cankhor & 5 cankhor \\
\hline
\end{tabular}

1 hat $=18^{\prime \prime} 1$ cankhor, the distance between thumb and little finger is equal to $9^{\prime \prime}$

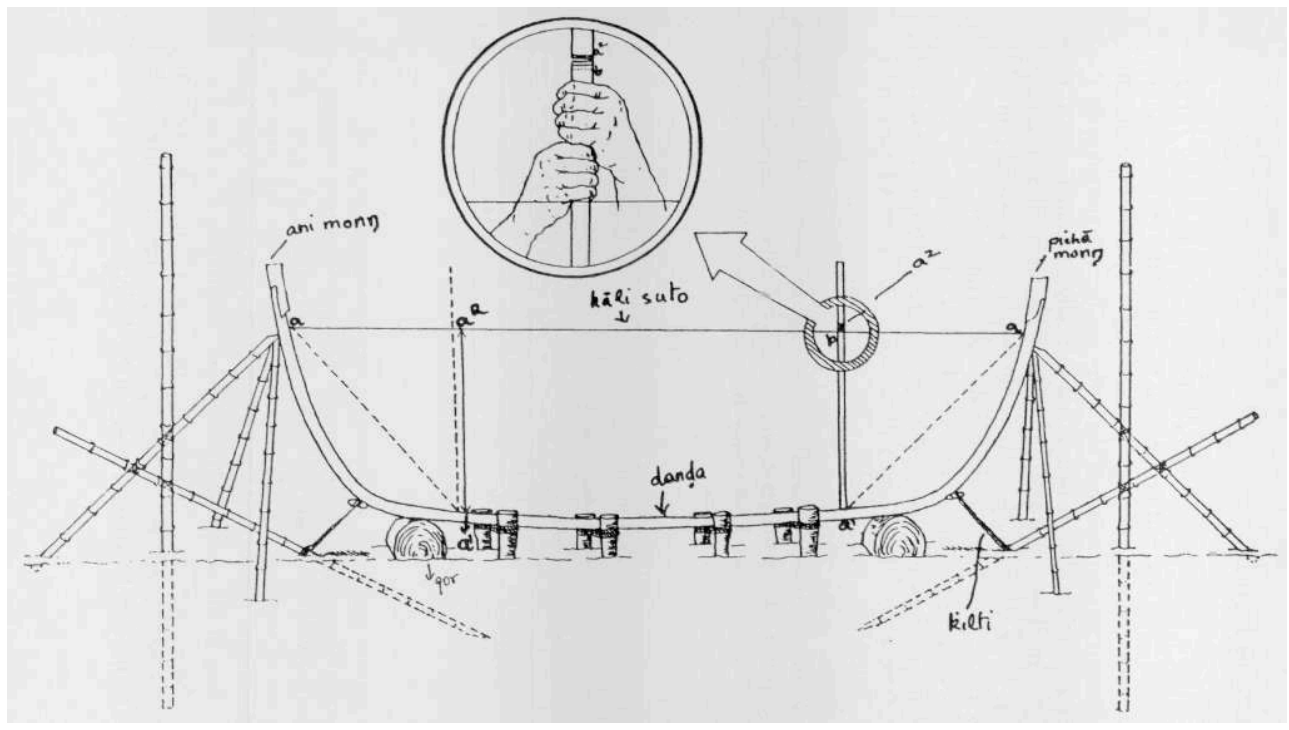

Figure 3. 1) Patia, support system, erection procedure and depth measurement. See how the danda is supported by the rope passing under it stretching between one peg and the other. Also to be noted is the placement of the kilti and its function in achieving keel curvature through exertion of an outward thrust by the rope and peg. Also shown is the method of taking the depth measurement by suspending a bamboo pole downward from the centrally aligned string, the kali suto, running from stem to stem. The depth of the stern will be less than that of the stem by $10 \mathrm{kar}$, finger widths. The inset shows that the distance al-b is equal to ten kar. 2) Progression in finger measurements taken as kar. Measurement is always initiated with the use of the forefinger, tarjoni. This is followed in progression by the middle finger, modhyoma, ring finger, anamika, and, finally, the little finger, konistha. After measuring 8 kar in this manner, the lower hand is removed and the middle and ring fingers of this hand are placed above the unit of four fingers already in position 


\section{Measurement of Depth}

According to Sudhir Jana, Digha, after the erection of the danda, a string, kali suto, is aligned from one end of the stem to that of the stern. A bamboo strip measuring one quarter the length of the string is then made, $a-a^{1}$. One end, $a$, is positioned at the ani, while the other reaches down to test on the danda at point $a^{1}$. The bamboo is then raised vertically at point al to cut the string at a point marked as $a^{2}$ The same process is repeated at the stern, picha. However, when the bamboo is placed upwards here, a second point, $\mathrm{b}$, is marked 10 to $12 \mathrm{kar}$, finger widths, below $a^{2}$. The point $\mathrm{b}$ marks the height at this section of the stern. This position is 10 to $12 \mathrm{kar}, 61 / 4^{\prime \prime}$ to $7.5^{\text {", less than }}$ the equivalent height at the stem in a patia 16 hat in length. If 1 kar is taken as equal to 5/8", 10 kar will measure $61 / 4 "$ and 12 kar can be taken as 7.5". The stem is thus higher than the stern in proportion to the length of the danda.

The information provided by Sudhir Jana, Digha, indicates the relative difference in depth between the stem and stern. This data is supplemented by the details obtained from Dhananjay Behera, village Udaypur, district Balasore, Orissa. This is listed below :

\begin{tabular}{|lll|}
\hline $\begin{array}{l}\text { Length of danda } \\
\text { from stem to stern }\end{array}$ & Length of string & Depth at majhu \\
\hline 16 hat & 13,5 hat & 3 hat \\
\hline 17 hat & 14 hat & 3 hat \\
\hline 18 hat & 15,5 hat & 3,5 hat \\
\hline 19 hat & 16 hat & 4 hat \\
\hline
\end{tabular}

\section{RELATION BETWEEN LENGTH AND DEPTH}

Since the patia is shell built all these calculations pre-determine the form to be given to the boat. Additional support is now provided to the danda by pegs driven at intervals of 18 " on both sides at ground level. A rope is tied from one peg across to the other side from under the danda. It is important to note that the central section of the patia hull is relatively straight, the main curvature occurring at the stem and stern regions. Planks are, therefore, bent in the meri kat for the two end sections and joined to a flatter plank constituting the central portion of the hull (photo 3). The outer curvature is facilitated in these sections by bevelling overlaps in plank alignments. 


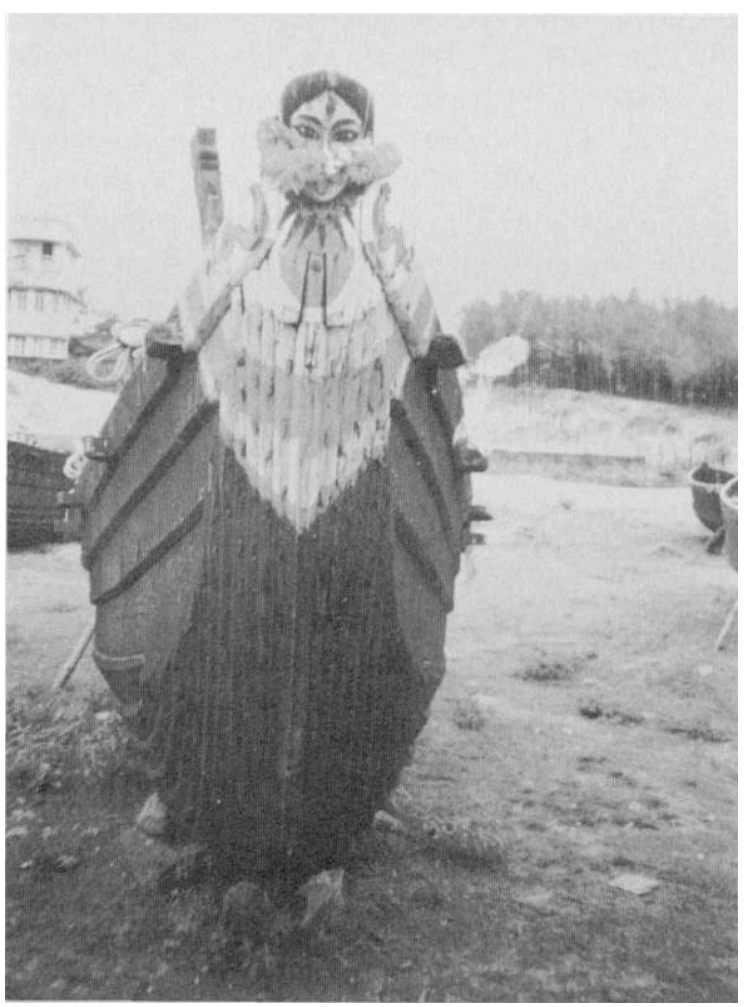

Photo 3. View of stem curvature in patia. Note how nails driven through inboard are twisted outboard

After the danda has been fixed into position the next plank, chapran, approximating a keelson, is laid on the danda. The chapran, 1 " in thickness and $4 "$ to $6 "$ in width, is fired and bent in the same manner as the danda. The tongue in groove joint is used in lengthening. The placement of the chapran commences from the mid-section of the danda. The chapran is slightly wider than the danda and prior to placement the carpenter rounds the edges to minimise friction. Holes are drilled from the chapran to the danda with the turpun, fiddle drill. Nails are then hammered out from the inner skin at intervals of between $4 "$ to $5 "$. As the nails are hammered outwards, these are twisted down on the outer skin. The chapran narrows down towards its two points of termination. Two posts are fixed at the terminal end of the chapran, at ani, stem and picha, stern. These posts are respectively called ani mong and picha mong. The ani mong has decorations on both sides while the picha mong is decorated only on the inner face. Babla, Acasia arabica, of the dimensions 1 hat in length, 7" in width, 3 " in thickness, is utilised. According to Dhananjoy Behera, aged 68, in the past only the pattern of the mali flower was carved. In present times, Kali, the protective deity of the boat, is also to be found depicted. On occasion, holes may be found pierced through the central part of the ani mong and the picha mong. The former is used as a conduit for releasing the rope of the anchor, while the latter can be used for tying the steering oar (photo 4).

The first row in reverse clinker starting from either side of the chapran is called andhli dhauri. This is $4 "$ wide at the central section. The overlap in reverse clinker at the centre is less that at the two ends. At the same time the plank itself is shaped and tapers towards the two ends. A section of about 1 suto ( $1 / 8 ")$ is removed with an adze along the connecting lower surface to provide an angular shape to the hull. The process of reducing the thickness and cutting away the surplus edge of the plank prior to joining is very slow as the surface has to be very even. 

gap of about 1" to 1,5" between the two andhli dhauri nailed onto the chapran. Prior to final nailing cowdung paste is applied to the section of the chapran on which the andhli dhauri is to be placed. The andhli dhauri is then clamped into position (photo 5). If any sections of the andhli dhauri are found dotted with cowdung residue after the removal of the jata (clamp), these are planed. The process is repeated until there is a perfectly even alignement. In earlier times this section was luted with a fine cotton cloth but this practice has fallen into disuse. After a perfect fit has been assured, holes are bored at regular intervals by the fiddle drill, turpun or bhomor, and the andhli dhauri is nailed onto the chapran.

The same procedure is followed for all subsequent planking present in the reverse clinker section. All planks have already been bent on the meri kat by firing. The second line is called dua, the third tia, the fourth couka and so on. The section with reverse clinker planking is called tala garon, meaning bottom planking. The number of such planks in the tala garon is related to the length of the patia. Thus :

\begin{tabular}{|cc|}
\hline Length in hat & Number of rows (dhaor) in tala garon \\
\hline 16 & 9 to 10 \\
\hline 17 & 11 \\
\hline 18 & 12 \\
\hline & And so on .... \\
\hline
\end{tabular}

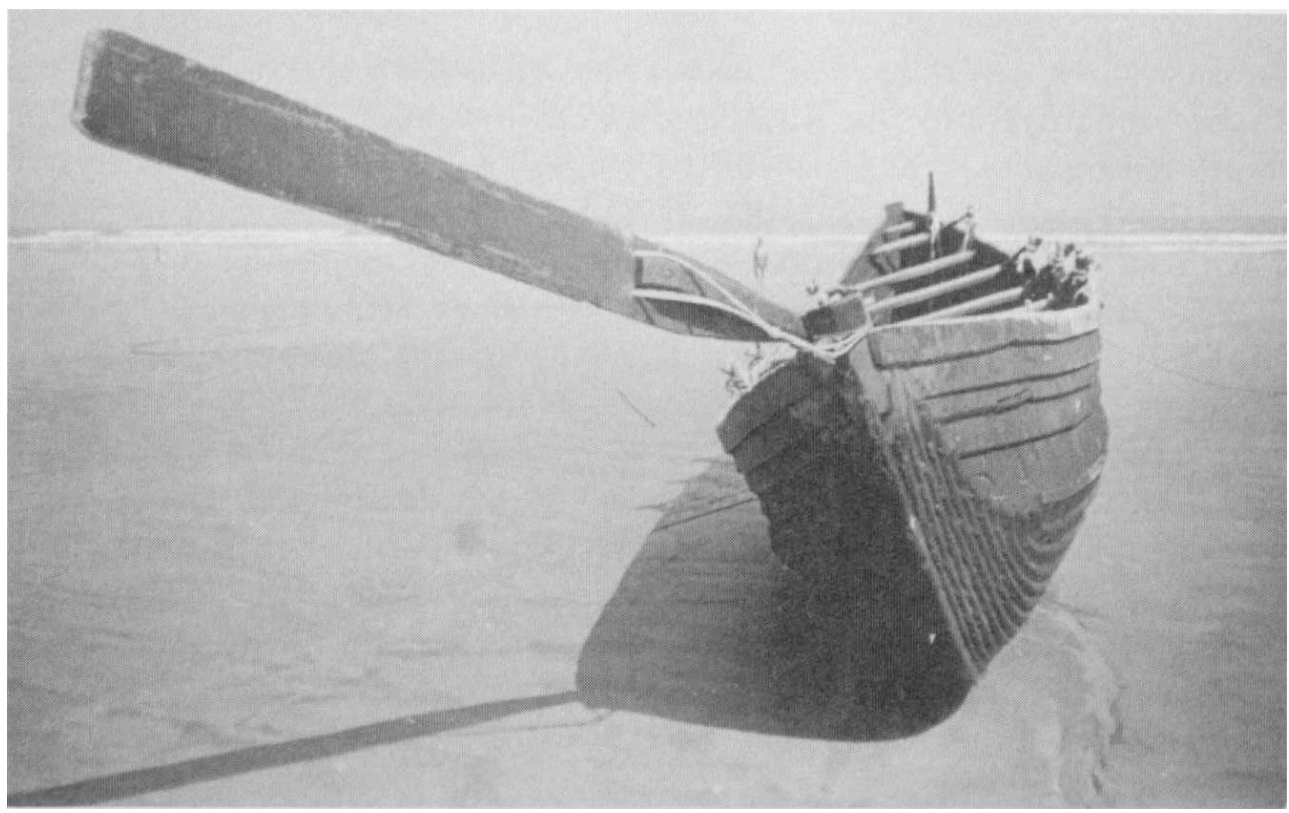

Photo 4. Hole in central part of picha mong used for tying steering oar 


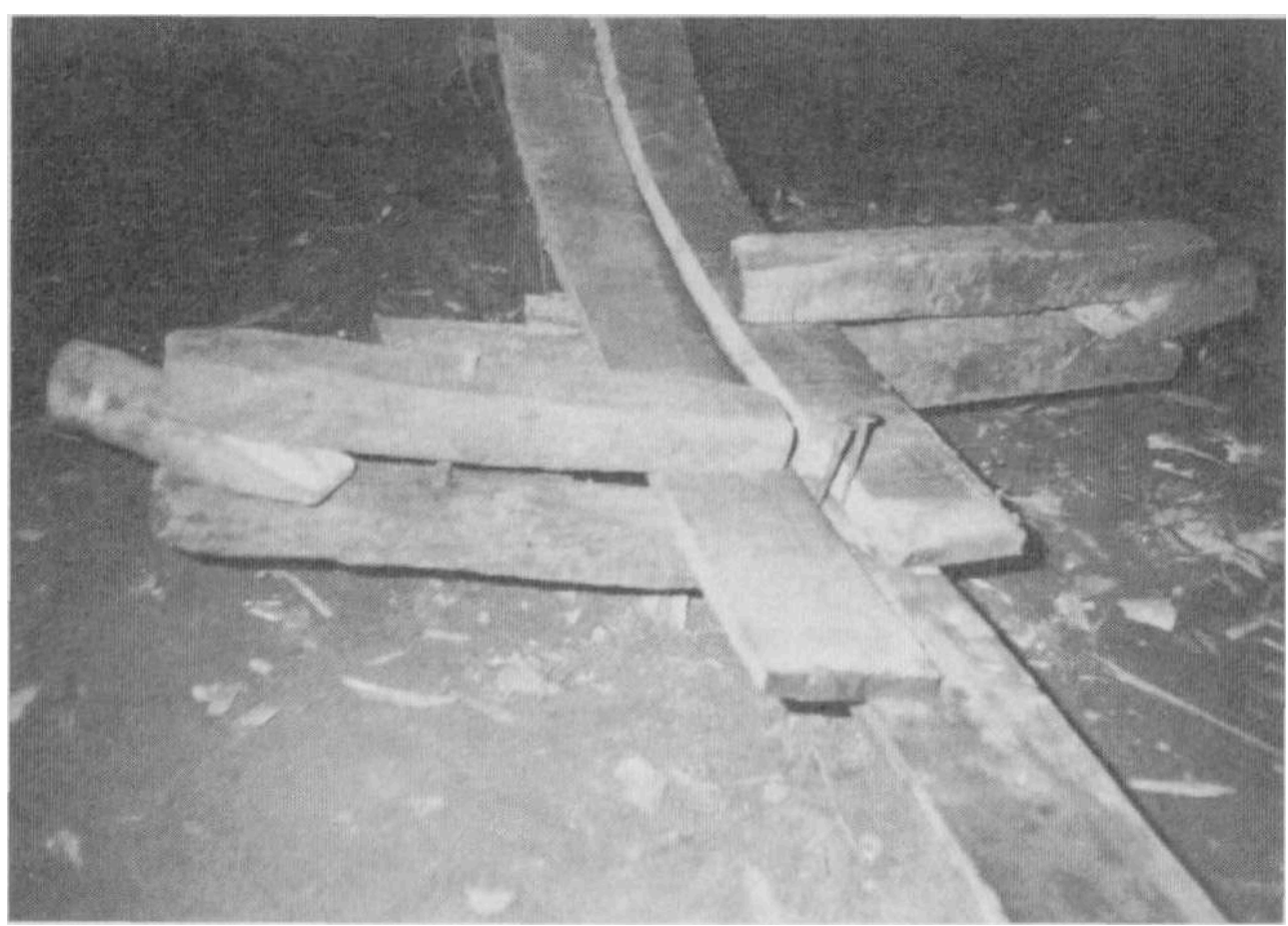

Photo 5. The two nails indicate the gap which will be maintained between the two andhli dauli. The distance between the two andhli dauli is continously assessed by a plumb line extended from the string line above. Note the temporary clamping with the jata to ensure proper fitting and its further tightening by the wooden peg on the left. The wooden jata used in patia building is similar to the metal kenchki used in Kakdwip. Dhaor is the term used for plank

21 In a 16 hat patia the andhli dhauri, as well as the dua and tia are 4 " wide at the central section. The 4th, 5th and 6th rows have a width of 5 " while the widest section at the centre of the 7th, 8th and 9th row is 6". The width of the last row, dantia, is 8 " (photo 6). Prior to nailing, the planks in the tala garon section are kept in postion by clamps. Eight to ten clamps may be used for this purpose. All the planks do not extend along the full length of the keel and keelson. There is a progressive shortening in length of plank used in tala garon between the andhli dhauri and the dantia (photo 7). At points of the termination towards stem and stern nails are positioned transversally (photo 8). Another feature is that bevelling to a depth of one suto is done only on the lower face of the danta. The width of the hull is equal to its depth at the central section of the completed patia. When this measurement of width is taken from the dantia, at the widest section of the tala garon of the boat, the depth is one-third the width. Bi-lateral symmetry is maintained in course of laying the tala garon by means string measurements taken. 


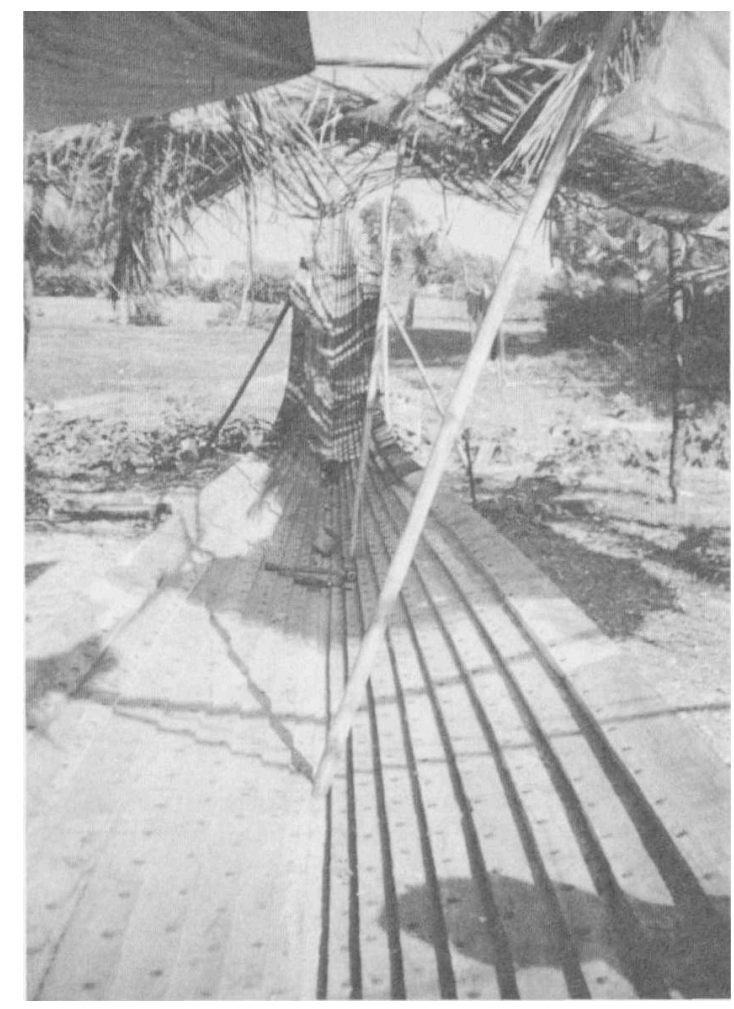

Photo 6. Tala garon. Note progressive increase in width and tapering towards ends

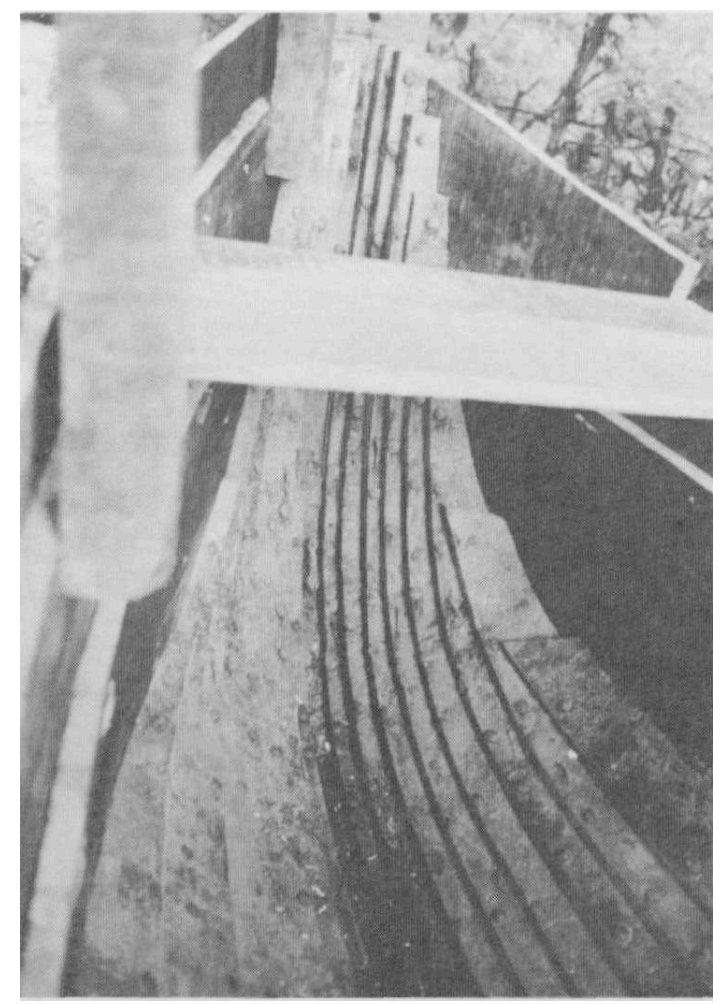

Photo 7. Note the progressive shortening in length of planks used in tala garon and string introduced through hole along chapran 


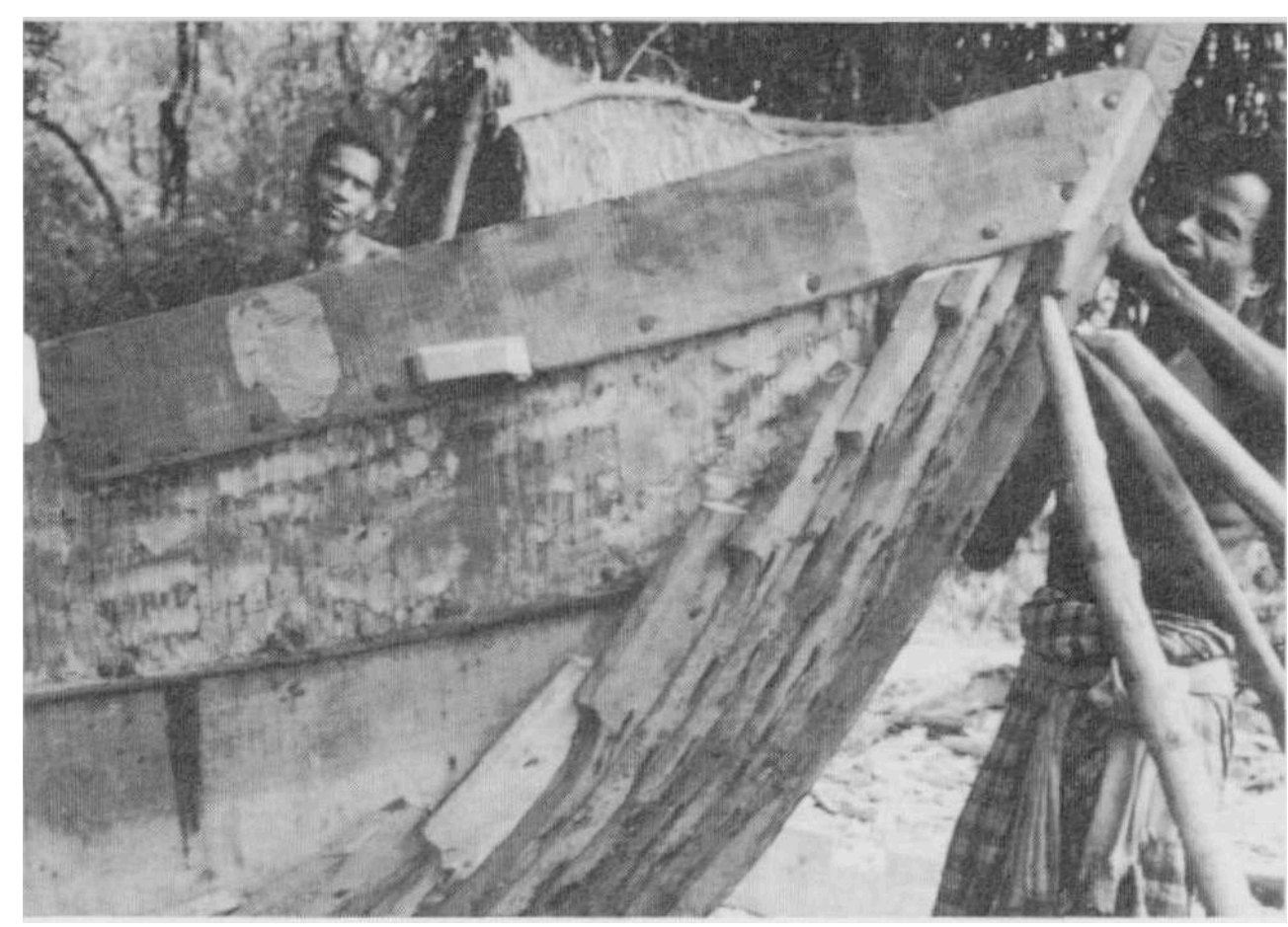

PHOTO 8. TOWARDS POINTS OF TERMINATION APPROACHING STEM AND STERN ENDS NAILS ARE DRIVEN TRANSVERSALLY INWARDS, OUTBOARD TO INBOARD

On finishing the tala garon section, soali, a plank 8 " to $10^{\prime \prime}$ in width and having a thickness of 1 " is joined to the dantia. If the thickness of the soali is taken as a, the width as $b$, and the length as $c$, the corresponding dimensions of the dantia could be taken as $a^{1}, b^{l}$ and $c^{1}$. The soali is laid along the lower section of a on the outer edge of $b^{1}$, the dantia running along $c^{1}$ (fig. 4). A certain sequence is followed in laying the planks at the tala garon section. Plank laying is started at the kilti section. However, the points at which lengthening of successive planks take place are staggered. After the construction of this section has been accomplished a different order is followed subsequent to the dantia plank. After the dantia, the planks are first laid at stem and stern ends and work proceeds progressively inwards. It is to be noted that the profile after dantia straightens out somewhat (see photo 3). After soali, the second line of planking, dua, is positioned. The topmost planking in this series is the gali chato. All the planks from dua to gali chato are clinker laid, and nailing is accomplished from outboard to inboard. The overlap in the clinker section is between 2" to 3". The vertical joint used in lengthening the planks is the tongue in groove called sada khaj. 


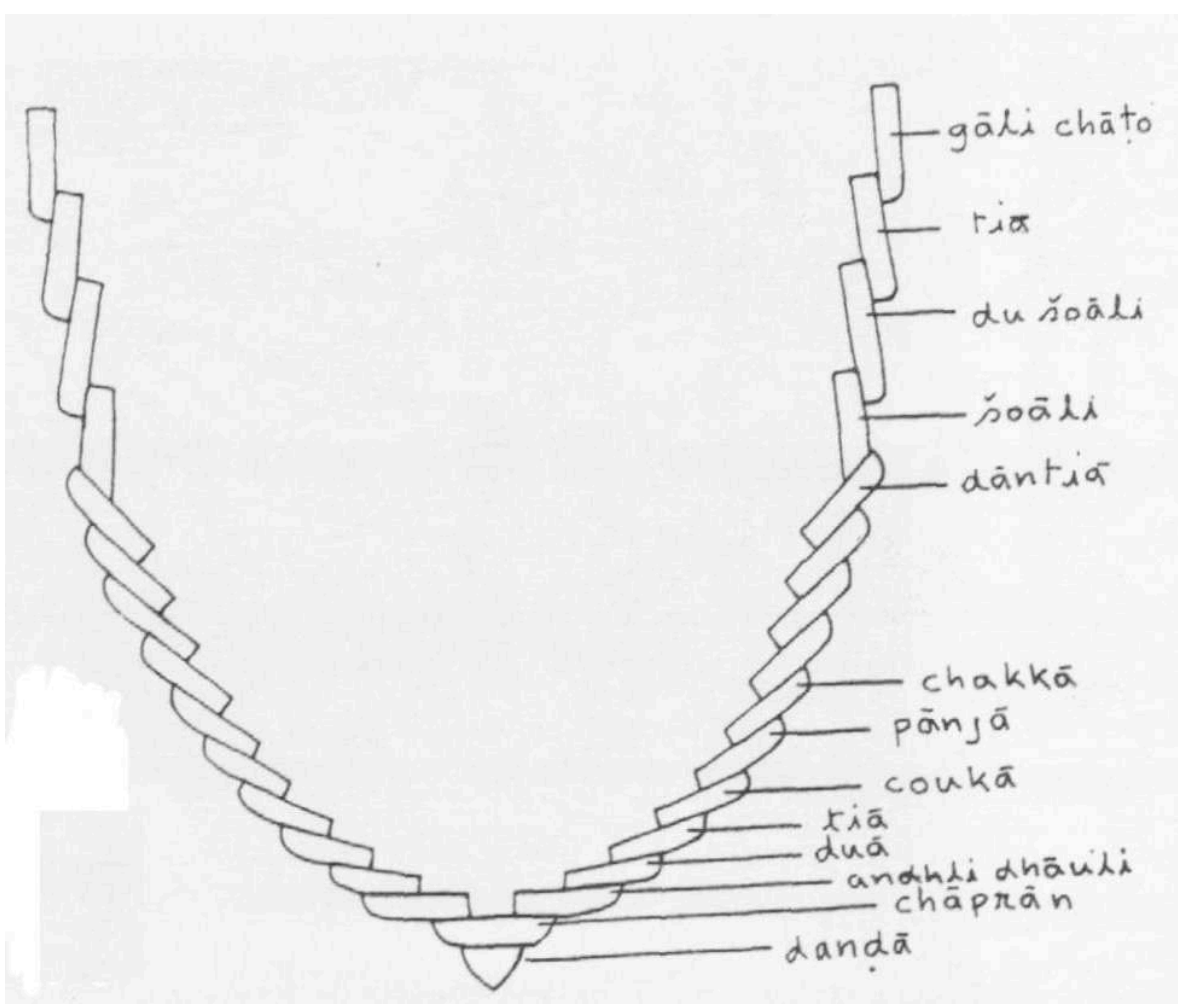

Figure 4. Medial width wise depiction in patia plank laying. Note reverse clinker between danda and dantia, carvel in lower face of soali and clinker between du soali and gali chato

Before the gali chato is placed grooves are made on the uppermost planking and cross planks, bari, are positioned. Since contact with water is minimal here a different species of wood such as babla, Acasia arabica, may be used here. In fixing bari first the planks are cut for setting the bari. The carpenter then balances himself across the outer edges and drills holes. The bari is then nailed in. The bari sticks out at the stem region to protect planks from external friction (see photo 8). At the stern end, however, from where the fishing nets are thrown, these protrusions are planed down.

After the hull has been shaped and the bari have been fitted the floor and side timbers are nailed in. The floor timber, bak, are placed up to the level of the soali (photo 9). The side frames, baras, are aligned between soali and gali chato (photo 10). Both elements are nailed. In patia which are longer that 22 hat additional strengthening is provided by two to three thwarts. The thei, constituents of the thwart, are virtually free standing as they are positioned securely between the bak and bari (see photo 10). The thwarts support the hull against the inward pressure exercised by wave movement.

\section{Partitions}

The Patia is partitioned into four compartments, each serving a different purpose. Starting from the stern end the first compartment is used for the fishing net, joal and is called joal gari. The second is for storing fish, called mach gari. This is positioned in majhu, the mid section of the boat. The third, where water accumulates, is called jal (water) gari. The last compartment is called gathi. It is used by boatmen for rest and sleep when out at sea. 


\section{Caulking}

A group called kala pati or gaoni, undertakes caulking operations. Suto, cotton wool, shaped into string form, is stuffed in with a blunt chisel (photo 11). There is no hard and fast rule about the practice of caulking. For some it borders on incest as the boat is taken to be a daughter. For others, caulking is legitimate if undertaken on boats constructed by others. However, it is considered a less skilful and this job fetches a lower emolument than carpentry.

Following the South Asian tradition, the patia is shored when not in use. In a patia of between 18 to 21 hat in length, there is a crew of seven to eight including one helmsman. A 16 hat patia has a crew of four comprising one helmsman, majhi and three rowers. The oar is called dar. The sail is square and a detachable mast step may be used.

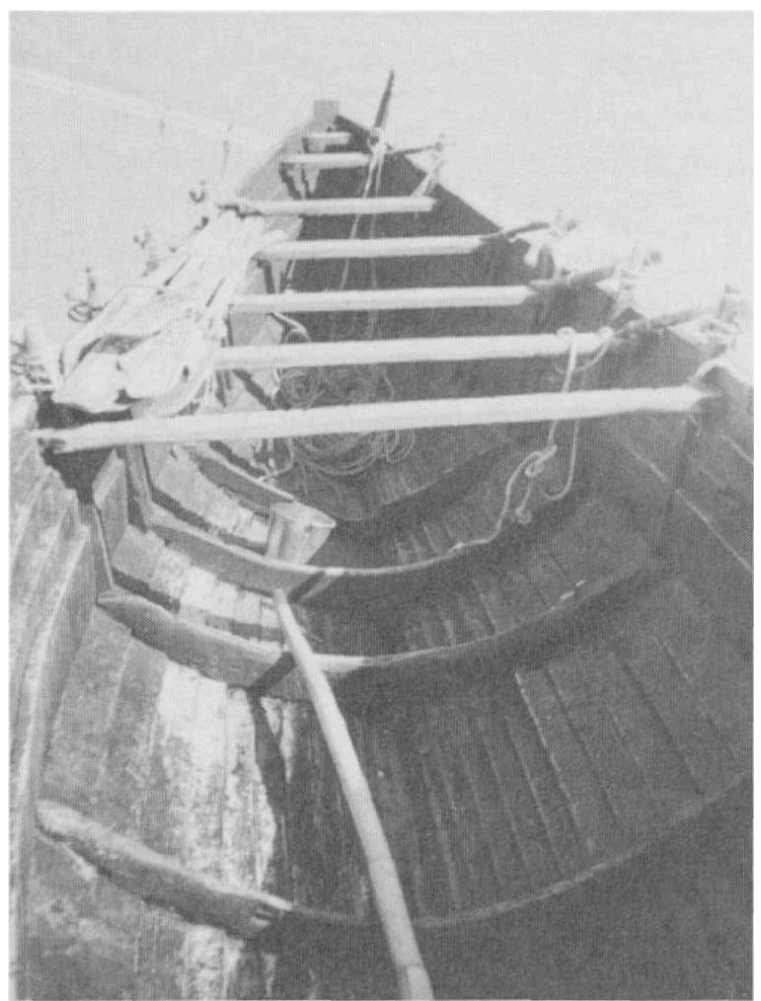

Photo 9. Note positioning of bari and terminal bari at stern end. The master carpenter is assessing placement of gali chat 


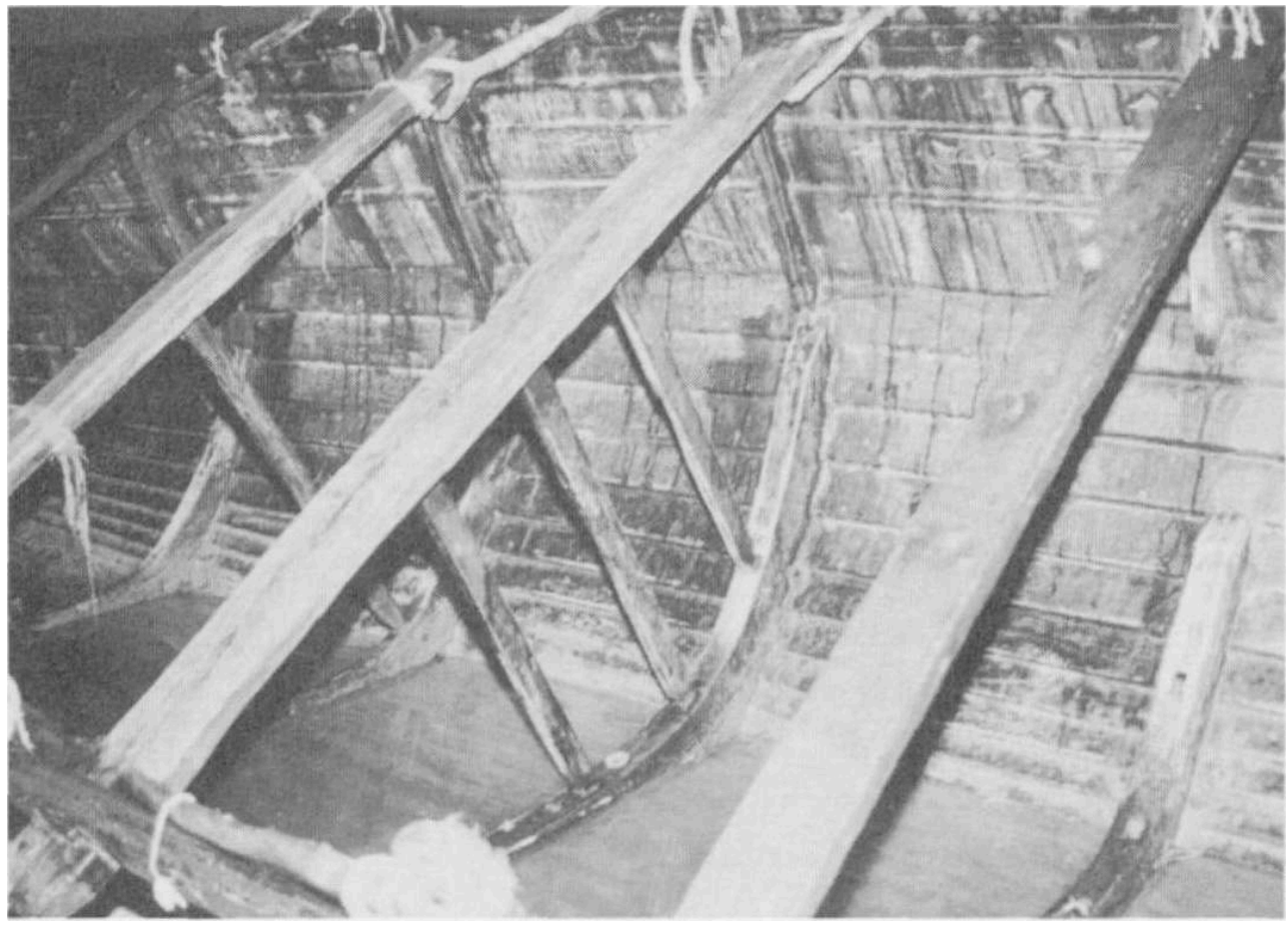

Photo 10. Bak placed upto the level of soali

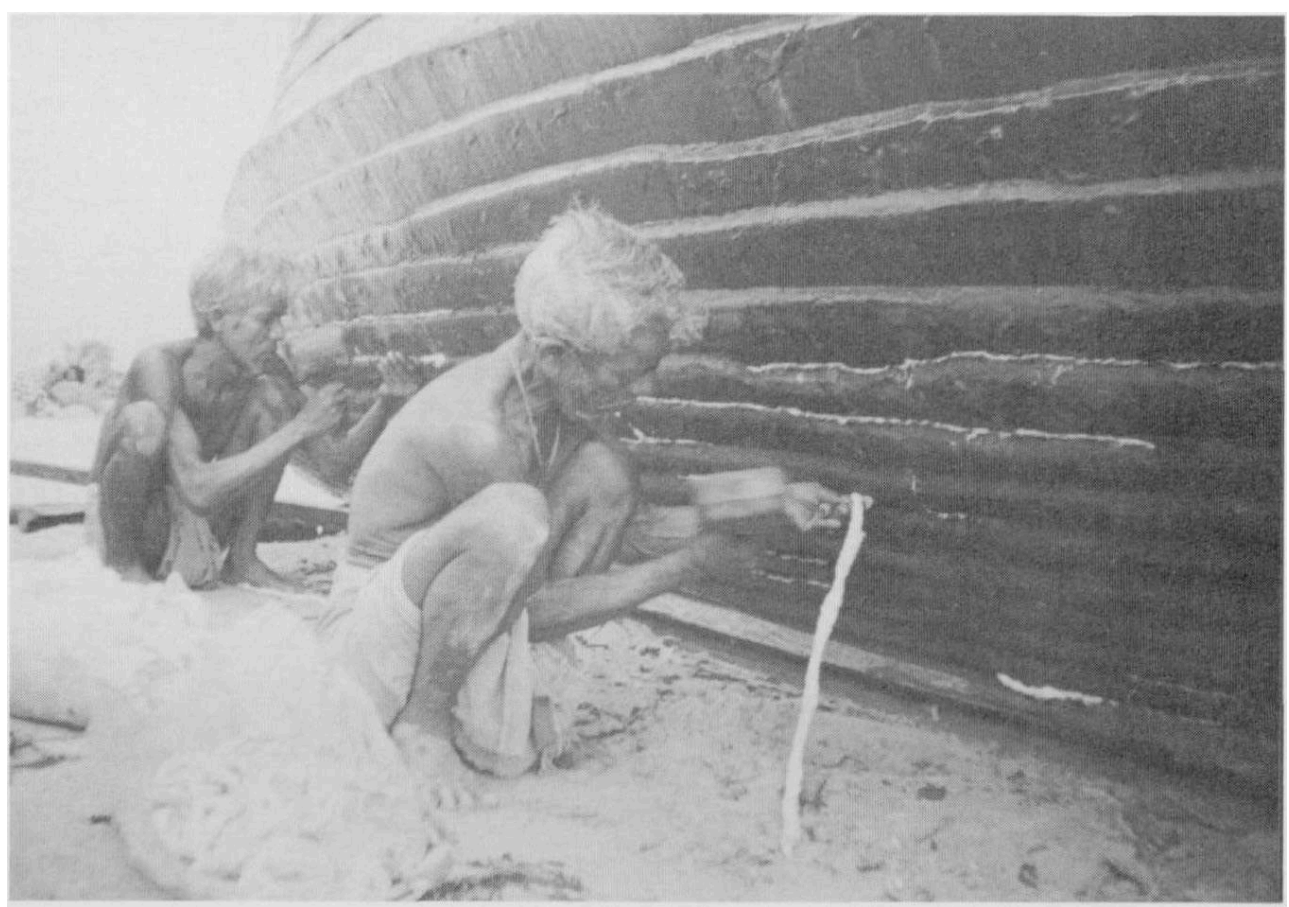

Photo 11. The gathi, used for repose at sea 


\section{Measurements of a selected Patia, about 19 hat in length}

\begin{tabular}{|lll|}
\hline Width & & \\
\hline From mid point, gali chato to gali chato & -- & $6^{\prime} 3^{\prime \prime}$ \\
\hline Quarter way from stern & -- & $5^{\prime} 3^{\prime \prime}$ \\
\hline Quarter way from stem & -- & $4^{\prime} 8^{\prime \prime}$ \\
\hline Maximum depth at centre & -- & $3^{\prime} 8^{\prime \prime}$ \\
\hline
\end{tabular}

Overall length measured end to end from gali chato : 28' 10"

This measurement of depth at majhu is the actual depth measured at mid points between the two gali chato and not that of the same points in relation to the tala garon section. With regard to the depth of 4 hat (6') which was projected through the string measurement taken in relation to the length of the danda prior to actual plank laying, it is important to remember that the actual depth would be approximately half that taken in terms of string measurement.

\begin{tabular}{|c|c|c|c|c|}
\hline Baka & $=$ & $\begin{array}{l}\text { Length } \\
\text { Breadth } \\
\text { Thickness -- }\end{array}$ & -- & $\begin{array}{l}4^{\prime} 10^{\prime \prime} \\
6^{\prime \prime} \\
1.5^{\prime}\end{array}$ \\
\hline Bak b & $=$ & $\begin{array}{l}\text { Length } \\
\text { Breadth } \\
\text { Thickness -- }\end{array}$ & -. & $\begin{array}{l}5^{\prime} 4^{\prime \prime} \\
6^{\prime \prime} \\
21 / 4^{\prime \prime}\end{array}$ \\
\hline$B a k \mathrm{c}$ & $=$ & $\begin{array}{l}\text { Length } \\
\text { Breadth } \\
\text { Thickness -- }\end{array}$ & -- & $\begin{array}{l}5 ' 8^{\prime \prime} \\
6 " \\
2 "\end{array}$ \\
\hline$B a k \mathrm{~d}$ & $=$ & $\begin{array}{l}\text { Length } \\
\text { Breadth } \\
\text { Thickness -- }\end{array}$ & -- & $\begin{array}{l}6^{\prime} \\
6^{\prime \prime} \\
1.5^{\prime \prime}\end{array}$ \\
\hline
\end{tabular}

Floor timbers, bak. Bak, stem to centre, in patia (fig. 5) 


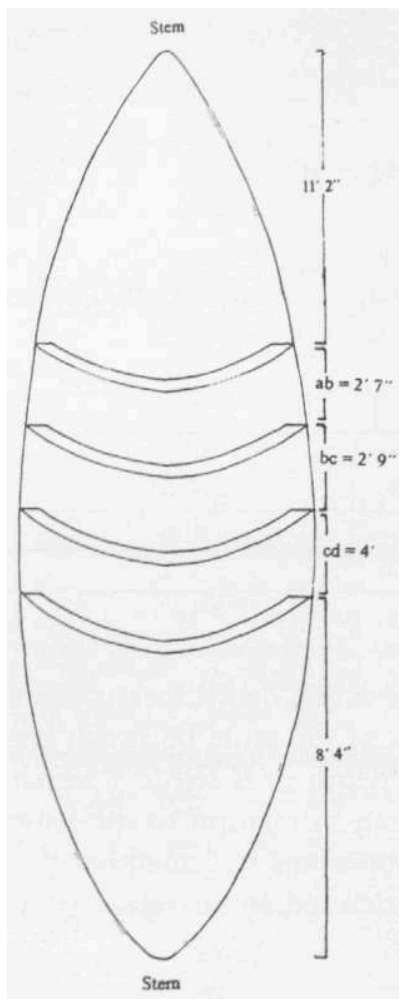

FIgURE 5. LOWER FACE OF DETACHABLE MAST STEP

Four pairs of baras were found. These were mast step disconnected from their corresponding bak. The baras were of variable length, running down from the top of andhli dhauri to gali chato.

Bari, cross beam, are seven in number (fig. 6), the last being positioned at a distance of 12 ' from the stern post.

\begin{tabular}{llll}
\hline $\mathrm{a}=$ & $1^{\prime} 1 " \times 3^{\prime \prime} \times 2^{\prime \prime}$ & $\mathrm{d}=$ & $5^{\prime} 2^{\prime \prime} \times 5^{\prime \prime} \times 2 "$ \\
$\mathrm{~b}=2^{\prime} 8^{\prime \prime} \times 4,5^{\prime \prime} \times 2^{\prime \prime}$ & $\mathrm{e}=$ & $6^{\prime} \times 5^{\prime \prime} \times 12 / 3^{\prime \prime}$ \\
$\mathrm{c}=4^{\prime} \times 6^{\prime \prime} \times 2^{\prime \prime}$ & $\mathrm{f}=$ & $6^{\prime} 6^{\prime \prime} \times 5^{\prime \prime} \times 12 / 3^{\prime \prime}$ \\
& & $\mathrm{g}=$ & $6^{\prime} 4^{\prime \prime} \times 4,5^{\prime \prime} \times 1,5^{\prime \prime}$
\end{tabular}

Quarter way from stem

4' 4"

Quarter way from stern --

3' 6"

Mid section

Depth 


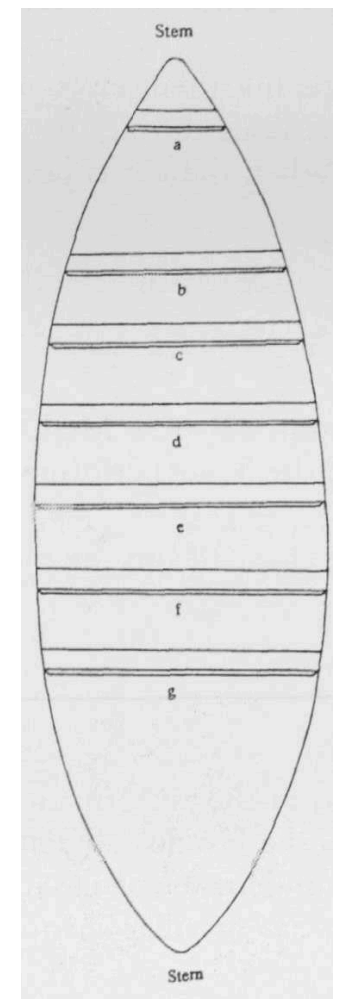

Figure 6. Placement of bak in patia. Viewed from above

\section{Patia Fishing}

31 According to Sarat Pattayyat, age 66, Shahabajpur Village, district Balasore, traditional fishermen of patia use a net called bhasali jal. This jal is made of monophil, synthetic yarn. In a patia having a keel length of 16 hat the net would weigh between 80 and 100 $\mathrm{kg}$. If the keel length were 23 hat the weight would be $150 \mathrm{~kg}$. The latter would measure about $600 \mathrm{bam}$, one bam being equal to 4 hat or $6^{\prime}$. The mesh size is $3 \mathrm{karah}$, one karah being equivalent to 1.5 ". There is a gap of 4 bam between one floater (sol) and the next and same distance is maintained between individual sinkers (caki). The sinkers and floaters are placed in the same vertical alignment along each edge of the net.

This is the basic net used by the traditional fishermen. Different meshes may be used in different months as the varieties of fish differ. In the Udaypur and Sahabajipur regions, district Balasore, the yearly cycle starts with the month of Baisakh. During the months of Magh and Phalgun, the mesh is of $105 \mathrm{~mm}$ and the net is called phas jal. For Asar and Sravan, the mesh is of 65 to $70 \mathrm{~mm}$ and is used for catching small fish. This jal is called ghoni jal. Both these can be taken as variations of the bhasali jal.

Fishermen go out to sea under oar always keeping themselves within sight of a known landmark. The square sail is only utilised during the return journey. Fishing is usually done during high tide. When the net is pulled in the catch is placed in the mach gari. 


\section{Rituals}

According to Sushil Kumar Acharya, near Duttapur, District Medinipur, there are three stages in boat building to mark which rituals are performed :

- nauka gothon, initiation of boat building ;

- nauka chalon, moment when the patia is to be shifted from the place of construction to some other place ;

- nauka jatra, the first launch.

\section{Danda Puja} ritual or religious ceremony pertaining to the Hindu religion. The danda puja can be accommodated under the rituals undertaken at the time of nauka gothon. According to Sushil Kumar Acharya, liko or village astrologer, a resident of Duttapur, district Medinipur, the first stage of danda (keel) puja is janmo dan (Imparting Life). On finding the auspicious moment the liko has to find out if the rasi, sign of zodiac, matches that of the owner. If not some other family member will be found with the same rasi, otherwise another date will be identified. The matching of rasi is important, as this individual, for all practical purposes, will officiate as the personification of the boat for ritual purposes.

The head, mistiri, rather than a priest performs the rites. Janmo dan can also be taken as Kali puja (puja to the goddess Kali). This ritual takes place prior to the commencement of boat building operations. On the chosen day the head carpenter will make a small hole in the selected piece of wood. A little gold and silver are incised into the wood. Cow's milk, champa flower, Michelia champaca, pada (lotus), Nelumbium nucifera, marigold, Tagetes erecta along with other flowers, sandalwood, vermilion, dhan, Orzya sativa, dubbo, Cynodon dactylon, parched rice, rice grains, banana, batasa (a form of sugar) and other fruit are then ritually blessed and distributed amoung the participants as prasad. A sari with a red border and a red piece of cloth, khaca, are also offered. The sari is taken by the mistiri. However, a supari, betel nut, Areca catechu, and a one-rupee coin are wrapped up in the khaca and this cloth is tied around the wood where the incision was made. Prior to this the ritual form of Kalapurush as sketched is etched on this spot. Kalapurush has a connotation of the deity Shiva. At the same time it is also associated with the constellation Orion. Orion is visible overhead during the winter months, at the time of the Northeast monsoon. This is the most favoured season for maritime activities. Along with this depiction an eye is also drawn symbolically suggesting the presence here of Sarbomongol (All Auspicious) Durga. This is taken to be the place where Durga or Kali will take up residence. When the keel will be laid this piece will also form part of the keel. An auspicious day is chosen when the keel will be raised. On that day, water of green coconut, Ganges water, milk, flowers, tulasi leaf, Ocimum sanctum, sandalwood, ghee, clarified butter, sesame seed and other ritual items are kept on the stem post. The stem post must face the direction decreed by the almanac. The stem head is taken as the place of residence of Brahma the stern post that of Shiva while the middle section of the danda is the home of Vishnu. The section on which Janmo Dan had earlier been performed is also worshipped as Kali is taken as a very powerful protective 
deity: there is no special ritual for Vishnu. However, it is believed that unless the trinity, Brahma, Vishnu and Shiva are propitiated, Kali will not descend into the boat.

Jal Dan, gift of water, is the next ritual to be performed. This marks the rite of nouka chalon. At the time of danda puja, the rasi of the patia had been selected. If the person who has the same horoscope as the boat happens to be of female sex, the person has to be either in the pre-menstrual or post-menstrual age group. This rite is performed when the boat is entirely finished and is to be handed over to the owner. The ceremony is also performed when the boat changes ownership. The person performing the ritual prior to transfer has to fast and a garland is to be placed on the stem. If available a second garland will be placed on the stern head. The stem and stern posts are decorated with jhuti, rice past, in circular dots. Vermilion is mixed with mustard oil and is also applied on the hull. The designs are made with kusa grass Desmostachys kipinnata (see fig. 5). Fruit and other ritual offerings are offered to the ani mong and picha mong, and also to the central section. In this way Brahma, Shiva, Vishnu and Kali and all propitiated. Incense sticks are lighted and conches blown at the moment when the previous owner, or his representative, pours Ganges water, milk, coconut water from a brass vessel, ghoti, from the stem head while the new owner, or his representative (the aspect of rasi plays a role here) receives this water on his/her head placed on the danda, keel section below the stem post (photo 12). This process is called jal grohon (« receiving water »). New clothes are worn on this occasion. A part of the offerings are left on the boat, the rest is distributed. This is a simple ceremony performed without complicated ritual and chanting. If the boat is not changing ownership the same ceremony is performed with the mistiri transfers the boat to the owner.

There is a variation in the symbolism of the rituals performed until the stage when the patia formally passes into the hands of the owner. The boat is created by the boat builder and the rite of danda puja simulates this through the ceremony of janmo dan. The sex of the child, the patia, is female and she is taken as the daughter of the master carpenter. After the completion of the patia it is handed over to the family of the owner, and the sense here is that of a daughter who is married and is then to proceed to the house of her husband. In Hindu Bengal this rite of passage is called samprodan. In the context of boat building ritual this is projected in terms of jal dan and jal grohon. It is significant that these ceremonies are accompanied by the use of vermilion paste as in a marriage ceremony. Once the boat is transferred into he hands of the owner, the relationship changes and the owner, the son, looks on the boat as his mother.

The next series of pujas forming part of nouka jatra are performed over a period of two days in the following order : 1) gram candi puja ;2) propitiation of other deities ; 3) joal puja ;4) nauka puja ;5) baluka puja. 


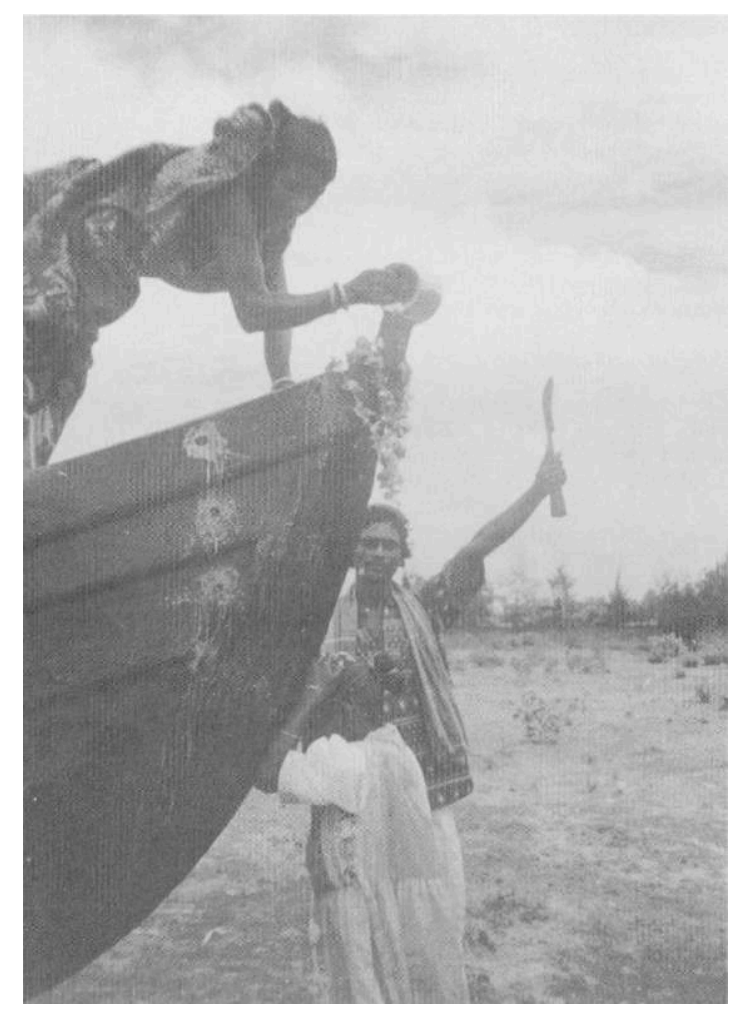

Photo 12. Placement of bari in patia. Viewed from above

\section{Gram Candi Puja}

43 A small pilgrimage is undertaken to the gram (village) shrine of Candi, a Mother Goddess (photo 13). This observance can be read at two levels. Any sacred tree can be worshipped as the embodiment of Candi, the mother goddess. The ani mong of discarded patia are placed below the tree and also worshipped. It is significant that when a boat is dismembered, all parts, with the exception of the ani mong, are recycled within the structures of domestic dwellings. This rite appears to be a projection of a belief in the symbiotic relationship between a living tree, the ani mong once the residence of Brahma and the ongoing domestic cycle of immediate activities such as the initiation of a new cycle of boat activities at sea.

\section{Propitiation of other Deities}

44 After gram Candi puja, visits are made to the local temples dedicated to Kali, Shiva and Sitala (diety of small pox) as well as the Chandaneshwar temple located in a village of the same name. (Informant: Santosh Pattayyat, Sahabajpur villave, district Balasore, Orissa). 


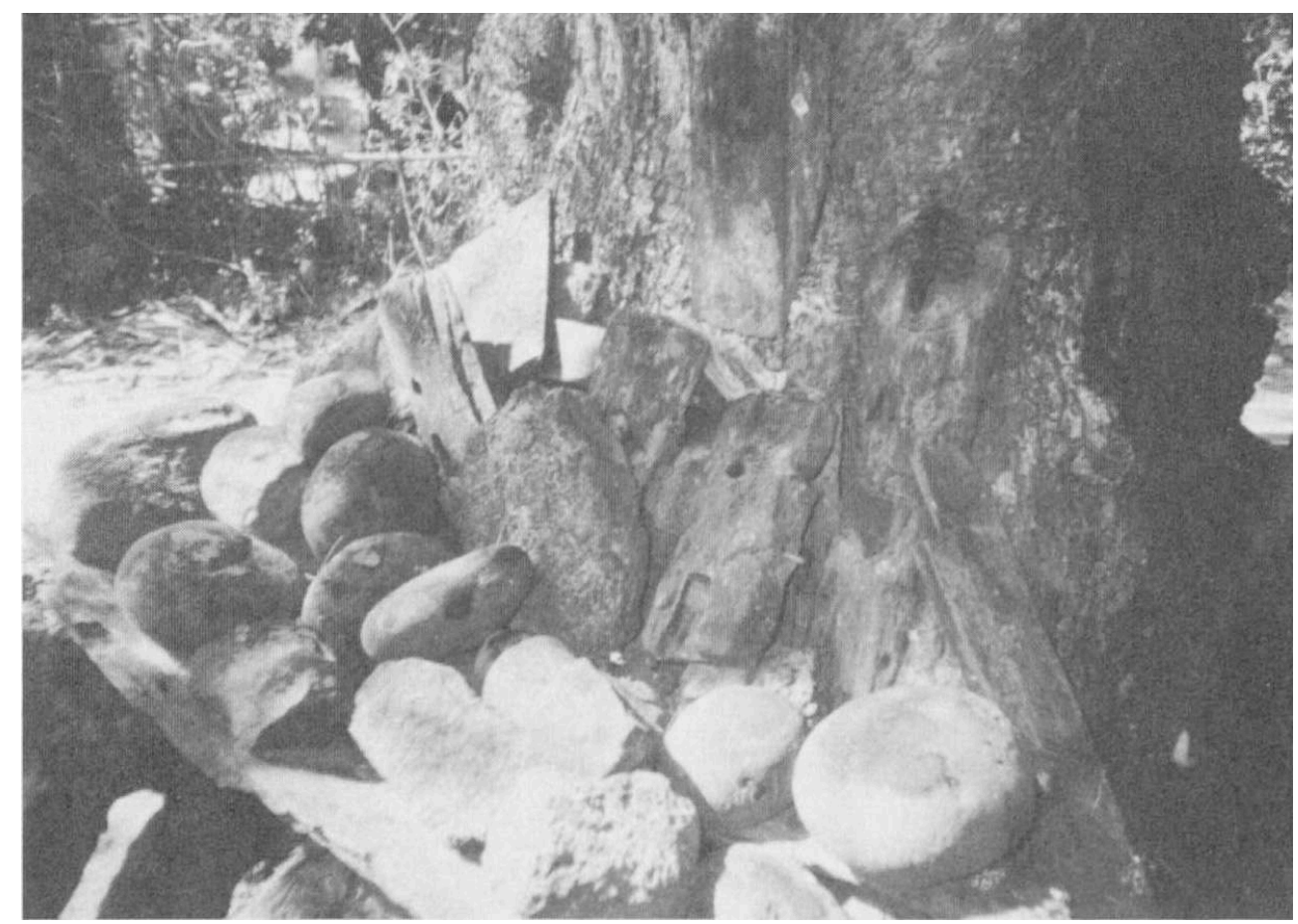

PHOTO 13. PREVIOUS OWNER HAVINg WATER POURED ONTO TO RECIPIENT REPRESENTATIVE OF NEW OWNER

\section{Joal Puja}

This is performed after the Candi puja and before Baluka puja. This appears to be an occupational rite to ensure a better catch of fish at sea. The fishing nets are carried from the home to the shore. These nets have different meshes depending on the size of the fish to be caught. The nets are laid out on the shore. At the auspicious moment the first knot is made tying two segments together. The joining procedure continues for a full day. After all the nets have been joined, two persons tie the floaters and two the sinkers.

\section{Nauka Puja}

Joal puja is followed by nauka puja. This is an extremely elaborate ritual over laid with much symbolism. In essence it signifies the cleansing of the boat, the abode of several deities. Only a few points are being described here. Ritual offerings are prepared in the house and these are brought to the shore. At the auspicious moment mustard oil is applied by the owner on the stem and stern post, on top of the tia, the central portion of the starboard side and on the steering oar. This is symbolical of the owner giving a bath and cleansing the patia. The same spots are brushed with a mango leaf, indicating teeth cleansing of the resident deities. Water is then poured, vermilion applied and garlands place on stem and stern. During this ceremony not only is the boat ritually cleansed but all presiding deities ate also propitiated. After this ceremony a red cloth, vastra, is tied around the stem head below the hole. Nauka puja is followed by Baluka puja. 


\section{Daria, Mahakal or Baluka Puja}

This is performed not only as a concluding part of the two-day ritual or nouka jatra but is also celebrated as an independent event when the patia is going out on its first fishing trip, or when the boat is going out after an interval of time. Although fishing is practiced through the year, there is abstention at certain times for a variety of reasons. The main gap in fishing occurs towards the close of Caitra when the nets are mended. Apart from this, Baluka Puja is performed once a year at the end of the month of Baisakh.

Daria is not only the term used for the sea but also carries the connotation of the Ganga, Jumna and Saraswati, the three sacred rivers. The designation, Mahakal is conferred on the trinity, Brahma, Vishnu and Maheshwar (Shiva). Baluka means sand. The three icons of Brahma, Vishnu and Shiva are worshipped in the aniconic form of pear shaped lumps of sand. The time for this ceremony is given by the liko or is determined after consulting the panjika, almanac. Worship is undertaken by the member of the owner's family who shares the same sign of zodiac at the time of birth as that assigned to the patia. The balls of sand finally disintegrate in the tidal waters and are washed away. The cycle of rituals culminating in Baluka Puja demonstrates that the patia is integrated into a whole cycle of belief systems of high ritual content. This is not to be found to the same degree in other segments of boat building activity in West Bengal. The cycle of rituals starting with Candi puja and ending with baluka puja simulate the chain of death (Candi puja), life in birth and maturity (nauka puja) followed by dissolution and rebirth (baluka puja).

pia is essentially a boat of Orissan typology. The chot is the traditional boat in the area contiguous to that in which the patia is to be found in West Bengal. The carpentry usages of the two boats are shaped by two distinct traditions. The chot follows the dominant West Bengal tradition being rabbeted and stapled. Neither of these elements is present in the patia.

This work has been funded by the Department of Ocean Development, Government of India, and carried out at the National Institute of Science and Technology and Development Studies, CSIR, New Delhi. Facilities provided by Director, NISTADS, are gratefully acknowledged.

\section{NOTES}

3. The main centres in Orissa include villages within the jurisdiction of the police station of Bhograi. Mention may be made of Kirtonia, Ranasingpur, Bichitrapur, Krishnanagar, Padmapur, Gompharia, Sahapur, Duttapur and Narayan Mohanti Paria. Others lie scattered along the banks of the river Subarnarekha comprising the villages of Bishnupur, Baliapal, Bodapal, Rosolpur, Sahabondor, Banskhana, Lakshmipatna. Noyabali, Paschimpar, Chursara and Ekiripal. The tradition spills over to Digha, situated on the coastline of West Bengal bordering Orissa. In this study major emphasis has been placed on the documentation undertaken at the village of Paschim Godadharpur, Post Office Digha, district Medinipur, West Bengal. Unlike the Balagarh 
dingi, which is essentially a riverine boat, the patia is well attuned to coastal waters, and, unlike the traditional boats of West Bengal, it has a keel.

4. The term sefti is probably derived from English, cubic feet, transpositioned as se denoting the $c$ (pronounced as s) in cubic and efti signifying feet.

\section{ABSTRACTS}

The major tradition in Bengal boat-building carpentry is that of edge to edge (carvel) joinery in planks to shape the hull. The patia, a sea-going fishing craft of the south Medinipur area of West Bengal, is rooted in a north Orissa tradition and represents a departure from this typology. Three types of plank joinery can be identified in specific sections of the hull - reverse clinker, carvel and clinker. Unlike the other West Bengal fishing boars, which are maneuvered essentially in riverine waters, the patia is used in coastal fishing. This article follows the course of the boat building procedure from initiation of construction to completion. The angle of vision is basically ethno-historical. Apart from technical processes and procedures, corresponding rituals and belief systems are also described. The text is essentially based on field generated data as the subject has been little explored from this perspective in archival and published sources.

Au Bengale, la tradition navale privilégie l'assemblage des planches bord à bord (cloué) pour le façonnage de la coque. Le patia, une embarcation de pêche en mer, que l'on trouve dans l'ouest du Bengale, dans le sud de Medinipur, est issue de la tradition du nord de la région d'Orissa et représente le point de départ d'une typologie. Trois types d'assemblage des planches peuvent être identifiés : à clins inversé, cloué, à clins. Cet article, fondé essentiellement sur des données d'enquêtes, examine d'un point de vue ethno-historique le processus de fabrication dans son ensemble. Parallèlement aux opérations techniques, sont décrits les systèmes de croyances et les rituels associés à la construction navale.

En Béngala, la tradición naval privilegia la construcción borde con borde clavada para la elaboración del casco. El patia, una embarcación destinada a la pesca de altura que se encuentra en el oeste de Bengala, al sur de Medinipur, procede de la tradición del norte de la región de Orissa y representa el origen de esta tipología. Se pueden identificar tres tipos de asemblaje de los tablones: de tingladillo invertido, asegurados con clavos y de tingladillo invertido. Este artículo se apoya por la mayor parte en datos de investigación; estudia desde el punto de vista etno-histórico el proceso de fabricación en su conjunto. Paralelamente a las operaciones técnicas se describen los sistemas de creencias y los rituales asociados a la construcción naval.

\section{INDEX}

Mots-clés: clin inversé, construction navale, patia, pêche, Inde de Test, système de croyances 


\section{AUTHORS}

\section{SWARUP BHATTACHARYA}

National Institute of Science, Technology and Development Studies, New Delhi, India. This work forms part of a larger project on « Boat Building and Fishing Communities - Bengal and the Andamans »

\section{LOTIKA VARADARAJAN}

National Institute of Science, Technology and Development Studies, New Delhi, India. This work forms part of a larger project on « Boat Building and Fishing Communities - Bengal and the Andamans » 